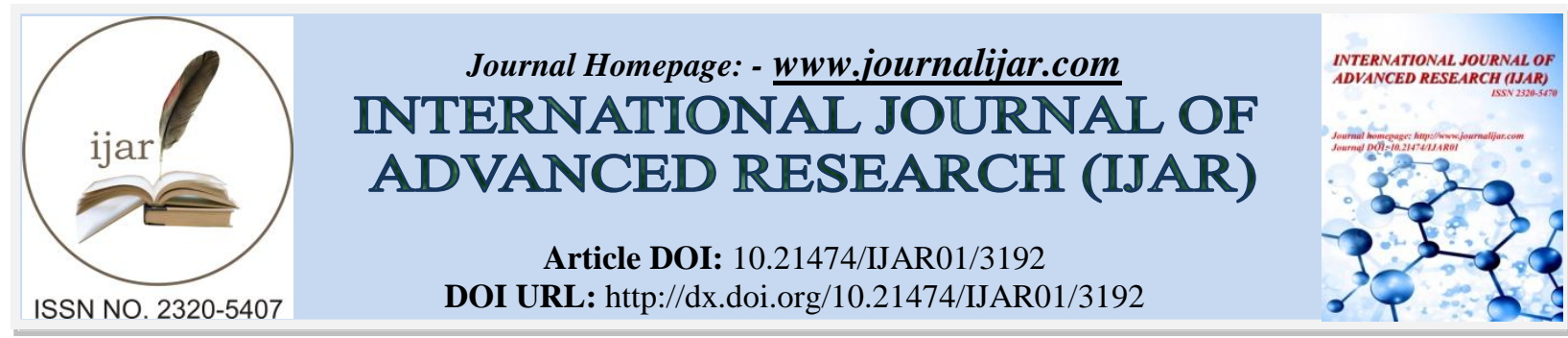

RESEARCH ARTICLE

\title{
DNA Barcoding and Phylogenetic analysis of South Indian Curcuma species using chloroplast matK gene.
}

Santhosh Kumar R. and Yusuf A."

Interuniversity centre for Plant Biotechnology, Department of Botany, University of Calicut, Kerala-673635, India.

\section{Manuscript Info}

Manuscript History

Received: 07 December 2016

Final Accepted: 15 January 2017

Published: February 2017

Key words:-

Curcuma, Phylogeny, matK, Neighbourjoining.

\section{Abstract}

The interspecific relationship between twenty one different Curcuma species was studied using MaturaseK gene (matK). Various Curcuma species are widely exploited for its medicinal, ornamental and other purpose. Floral plasticity in vegetative characters and developmental portion of inflorescence is widely utilized in morphology based classification which leads to erroneous conclusions makes DNA barcoding an essential tool for deciphering the correct identify and pohylogenetic relationship between the species. The sequence of matK gene of Curcuma sp with no barcode gaps were cloned, sequenced and submitted in the Genbank and used for the phylogenetic study. The intra and interspecfic divergence between the species assessed by using K2P of MEGA 6.0.The sequence alignments were performed using Clustal W,transition/transversion rates were predicted and phylogenetic tree was constructed using MEGA 6.Phylogenetic tree was designed to identify the ideal regions of Curcuma species for defining inter and intra-species relationships. The phylogenetic analysis using MEGA 6.0 provided two groups with the second group having two subclades. The study revealed the potential of $m a t \mathrm{~K}$ gene as a good candidate gene for phylogenetic analysis of the genus Curcuma.

Copy Right, IJAR, 2017,. All rights reserved.

\section{Introduction:-}

The genus Curcuma L. (Zingiberaceae) comprises of 120 species, widely used is spices, medicines, dyes and as ornamental plants (Skornickova et al., 2007). It is distributed in Asia, Australia and South Pacific (Larsen,et al., 1998; Wu and Larsen, 2000; Ye,et al., 2008; Chen and Xia, 2010). Twenty species and one variety have been reported from South India (Sabu 2006). The taxonomic identification of the genus is difficult and displays certain systematic problems due to morphological variation at the intraspecific level. The flowering season of Curcuma species is short and the floral morphology has higher similarity among the species, but differs in colors and inflorescence positions (Bakhuizen van den Brink,Jr 1968; Burtt, 1972). Phenotypic plasticity of the species can lead to wrong taxonomic treatment and identification of individuals. According to Kress et al., (2002), nuclear and plastid (ITS \& matK) genes can be used for phylogenetic analysis of Curcuma (Zingiberaceae) species.

The constructed phylogenetic trees can be used to study the evolutionary history of living organism and also provide the evidence of climatic and geological history of the earth. A phylogenetic tree displays the relationship of taxonomic groups in a hierarchical order (Futuyma, 2005). Molecular phylogenetic methods are mainly used in the perspectives of biological systematics, and are used for a wide variety of application, such as community ecology 
(Webb et al., 2002) proteomics, as well as inference of protein-protein interactions (Pazos and Valencia, 2001). Zheng and Xia (2010) used two sequences of ITS and matK to study the phylogenetic evolution of the tribe Zingiberaceae. Phylogenetic relationships between Curcuma species was studied using the cytological data (Chen et al., 1984)and RAPD fingerprinting (Xiao et al.,2000, Rajeshkumar et al.,2016).Ngambriabsakul et al.,(2004) observed that Curcuma is a paraphyletic genus in which infrageneric relationships are more complicated.

For the identification of species variation DNA barcodes are being utilized (Hebert et al., 2003). They are small size DNA of the organelle or nuclear genome with high discriminatory power among the organisms.DNA barcodes have multifarious role in the identification of the plants having problematic taxonomic identity for biodiversity investigation, the identification of cryptic or polymorphic plant species, food adulterants and forensic sample etc . The matK gene is one of the protein coding regions of plastid which is widely used to decipher the coding regions of DNA (Wolfe, 1991). This chloroplast gene is 1500 bp long, located within the intron of the trnK and codes for maturase like protein (Wolfe et al., 1992). This gene has high substitution rates within the same species and is a potential candidate to study plant systematics and evolution (Notredame, 2000). The polymorphism of chloroplast DNA regions comprising $t r n \mathrm{~K}, m a t \mathrm{~K}$ and intergenic $t r n L-t r n F$ have been used to study the phylogenetic evolution of various plants species (Wolfe, 1987). Studies using matK gene are used to resolve intergeneric or interspecific relations among flowering plants, like Malpighiaceae (Cameron et al., 2001), Poaceae (Liang and Hilu, 1996), Cornaceae (Xiang et al., 1998), Nicotiana (Aoki and Ito 2000), Orchidaceae (Goldman et al., 2001; Salazar et al., 2003) and in many other angiosperms (Hiluet al., 2003).

This paper reports the elucidation phylogenetic relationships between 21 different species of curcuma by using the chloroplast mat $\mathrm{K}$ gene sequence.

\section{Materials and Method:- Collection of Samples:-}

Twenty one different Curcuma species including one variety were collected from different regions of South India. These plants were maintained in Department of Botany, University of Calicut, and the leaf samples were used for DNA extraction.

DNA Isolation and Purification:-

Genomic DNA was isolated from fresh Curcuma leaves using modified CTAB method (Doyle and Doyle, 1987). Extraction buffer contained $2 \%(\mathrm{w} / \mathrm{v}) \mathrm{CTAB}, 1 \mathrm{MTris}-\mathrm{HCl}(\mathrm{pH} 8), .5 \mathrm{M}$ EDTA $(\mathrm{pH} 8)$ and $5 \mathrm{M} \mathrm{NaCl}$. The samples were powdered in liquid $\mathrm{N}_{2}$ and the powder was transferred to pre-heated $\left(65^{\circ} \mathrm{C}\right) \mathrm{CTAB}$ buffer. $2 \%$ (w/v) of PVP was added at the time of homogenization. Proteinase K $(10 \mathrm{mg} / \mathrm{ml})$ and $2 \%(\mathrm{w} / \mathrm{v}) \beta$-mercaptoethanol were added to the extract and mixed well. Samples were incubated at $60^{\circ} \mathrm{C}$ for $60 \mathrm{~min}$ with frequent mixing. The extract was centrifuged at $4^{\circ} \mathrm{C}$ for $12 \mathrm{~min}$ at $12,000 \mathrm{rpm}$ and the supernatant was collected in a new Eppendorf tube. Added equal volume of chloroform: isoamyl alcohol (24:1) to the supernatant and centrifuged at $4^{\circ} \mathrm{C}$ for 12 min at 12,000 rpm. The supernatant was extracted twice with equal volume of phenol: chloroform: isoamyl alcohol (25:24:1), followed by extraction with chloroform: isoamylalcohol (24:1), and centrifuged at 12,000 rpm $4^{\circ} \mathrm{C}$ for $12 \mathrm{~min}$. The supernatant was transferred to a fresh Eppendorf tube and one by third volume of chilled isopropyl alcohol was added, and incubated for one hour at $-80^{\circ} \mathrm{C}$. The sample was centrifuged at $4^{\circ} \mathrm{C}$ for $12 \mathrm{~min}$. at $12,000 \mathrm{rpm}$ and the pellet was dissolved in TE. $10 \mu \mathrm{l}$ of RNase was added to dissolve DNA sample. Incubated at $40^{\circ} \mathrm{C}$ for 30 min and added equal volume of chloroform: isoamyl alcohol (24:1) mixed well and centrifuged at $4{ }^{\circ} \mathrm{C}$ for $12,000 \mathrm{rpm}$. The upper layer was transferred to a fresh Eppendorf tube and added chilled isopropyl alcohol and mixed well. The samples were incubated at $-80^{\circ} \mathrm{C}$ for one and half hours and centrifuged at $4^{\circ} \mathrm{C}$ for $12 \mathrm{~min}$ at $12,000 \mathrm{rpm}$ to pellet the DNA. DNA pellet was washed with $70 \%(\mathrm{v} / \mathrm{v})$ chilled ethanol and air dried at room temperature and redissolved in $20 \mu \mathrm{l}$ TE buffer. This purified DNA was stored at $-80^{\circ} \mathrm{C}$.

\section{Quantitative and qualitative assessment of DNA samples:-}

Quality and quantity of DNA samples were assessed using a nanodrop spectrophotometer (Thermo, USA). The samples were run on $1 \%(\mathrm{w} / \mathrm{v})$ agarose gel and visualized to assess the DNA quality using a gel documentation system.

\section{PCR amplification:-}

The PCR reactions were conducted in a final volume of $25 \mu$ l containing 10x Buffer $2.5 \mu 1$, Taq DNA Polymerase $(1 \mu \mathrm{l})$, dNTP $\operatorname{mix}(10 \mathrm{mmol}), \mathrm{MgCl}_{2}(50 \mathrm{mmol})$, Forward primer $(88.4 \mathrm{nmol})$, Reverse primer (72.4nmol),Template 


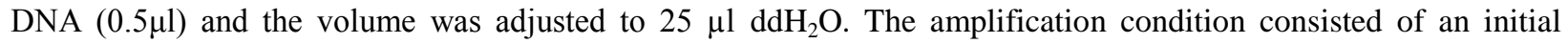
denaturation at $94^{\circ} \mathrm{C}$ for $2 \mathrm{~min}$, denaturation at $94^{\circ} \mathrm{C}$ for $15 \mathrm{sec}$, annealing gradient at 53 to $57^{\circ} \mathrm{C}$ for $30 \mathrm{sec}$, extension at $72^{\circ} \mathrm{C}$ for $1 \mathrm{~min}$. and final extension at $72^{\circ} \mathrm{C}$ for $10 \mathrm{~min}$. After amplification the PCR product was checked using electrophoresis on a $1 \%(\mathrm{w} / \mathrm{v})$ agarose gel and the band was eluted and purified by Minigel purification kit (Takara, Japan). Sequencing was done from Scigenom Lab Pvt, Ltd (Cochin, Kerala), on a charge basis.

\section{matK data analysis:-}

The Twenty one DNA sequences of the all samples were minimally edited and manually aligned using BioEdit software. The analysis of DNA sequences was conducted by Neighbour-joining to assess topology with MEGA 6.0. All the regions containing gaps and missing data were eliminated. The species identification and homology between the sequences was identified using BLAST method. The phylogenetic tree was developed using Neighbour-joining (NJ) method which was tested with Kimura 2-parameter for evolutionary distances in MEGA6.0 and node support was assessed on 1000 bootstrap replicates.

\section{Results:-}

The annealing temperature $55.6^{\circ} \mathrm{C}$ was found to be ideal to develop a high intensity molecular size band for mat $\mathrm{K}$. PCR and sequencing success rate was very high for all the twenty one species in the matK region $(99.0 \%$ of individuals, $100 \%$ species) with a PCR product size of $800 \mathrm{bp}$ (Fig1). The coding region of matK obtained from the 21 species was sequenced and the sequence was submitted to the Genbank of NCBI and the accession numbers were provided by $\quad$ NCBI; $\quad$ KU934093, KU736742, $\quad$ KX170829,KX455852, KX455853,KX455854,KX455855,KX148521,KX418654,KX650813,KX650814,KX650815,KX650816,KX650817 ,KX650818,KX650819,KX650820,KX650811,KX650809,KX650810and KX650812. The sequences were used to construct the phylogenetic tree, having twenty one informative sites and the overall mean distance of all sequences was 0.108 .The transition/transversion range between the species was 1.27.Tajima's Neutrality Test was conducted for all twenty one sequences to compare the number of segregating sites per site with the nucleotide diversity(Tajima, 1989)(Table 1).

The phylogenetic tree comprised of two groups in NJ-analysis; Group 1contained Curcuma raktakanta and Curcuma aromatica showed no variation as they was represented with a 100\% bootstrap value (Fig2). Group II has two branches and two monoclade, branch 1 has two clade A\& B and two monoclade Curcuma kudagensis and curcuma neilgherrensis which comes under clade A with $41 \%$ similarity and curcuma mutabilis and Curcuma oligantha var.lutea comes under the clade B showed similarity with $51 \%$ Curcuma karnatakensis, Curcuma oligantha var.oligantha and Curcuma coriacea exist as a monoclade. Branch II has two clade C and D, Clade C has one subclade and two monoclade Curcuma haritha and Curcuma aeruginosa comes under same clade and Curcuma vamana and Curcuma zanthorrhiza which excisted as a monoclade. Clade $\mathrm{D}$ has three subclade $\mathrm{D}_{1}, \mathrm{D}_{2} \& \mathrm{D}_{3}$, Curcuma longa and curcuma pseudomontana which comes under the same clade. Similarly Curcuma amada and Curucma decipiens represent the same. Curcuma Montana and Curcuma ecalcarata which comes under subclade $\mathrm{D}_{1}$ with $46 \%$ similarity. Curcuma inodora and Curcuma bhatii existed as a monoclade.

Maximum Composite Likelihood Estimate pattern of nucleotide substitution was obtained where each entry showed the probability of substitution (r) from one base (row) to another base (column) (Table 2). For simplicity, the sum of $r$ values is made equal to 100. Rates of different transitional substitutions are shown in bold and those of transversionsal substitutions are shown in italics (Table2). The nucleotide frequency was 32.16\% (A), 39.91\% $(\mathrm{T} / \mathrm{U}), 15.47 \%(\mathrm{C})$, and $12.46 \%(\mathrm{G})$. The transition/transversion rate ratios was $k_{1}=5.744$ (purines) and $k_{2}=2.54$ (pyrimidines). The overall transition/transversion ratio was $R=1.566$, where $R=\quad\left[\mathrm{A}^{*} \mathrm{G}^{*} k_{l}+\right.$ $\left.\mathrm{T} * \mathrm{C} * k_{2}\right] /[(\mathrm{A}+\mathrm{G}) *(\mathrm{~T}+\mathrm{C})]$.

Table 1:- Results from Tajima's Neutrality Test

\begin{tabular}{|l|l|l|l|l|l|}
\hline $\boldsymbol{m}$ & $\boldsymbol{S}$ & $\boldsymbol{p}_{\mathbf{s}}$ & $\boldsymbol{\Theta}$ & $\boldsymbol{\pi}$ & $\boldsymbol{D}$ \\
\hline 21 & 362 & 0.44691 & 0.124221 & 0.071099 & -1.767785 \\
\hline
\end{tabular}

$m=$ number of sequences, $n=$ total number of sites, $S=$ Number of segregating sites, $p_{\mathrm{s}}=S / n, \Theta=p_{\mathrm{s}} / \mathrm{a}_{1}, \pi=$ nucleotide diversity, and $D$ is the Tajima test statistics 
Table 2.Maximum Composite Likelihood Estimate of the Pattern of Nucleotide Substitution

\begin{tabular}{|c|c|c|c|c|}
\hline & $\mathbf{A}$ & $\mathbf{T}$ & $\mathbf{C}$ & $\mathbf{G}$ \\
\hline $\mathbf{A}$ & - & 6.69 & 2.59 & 11.99 \\
\hline $\mathbf{T}$ & 5.39 & - & 6.58 & 2.09 \\
\hline $\mathrm{C}$ & 5.39 & 16.98 & - & 2.09 \\
\hline $\mathbf{G}$ & 30.94 & 6.69 & 2.59 & - \\
\hline
\end{tabular}

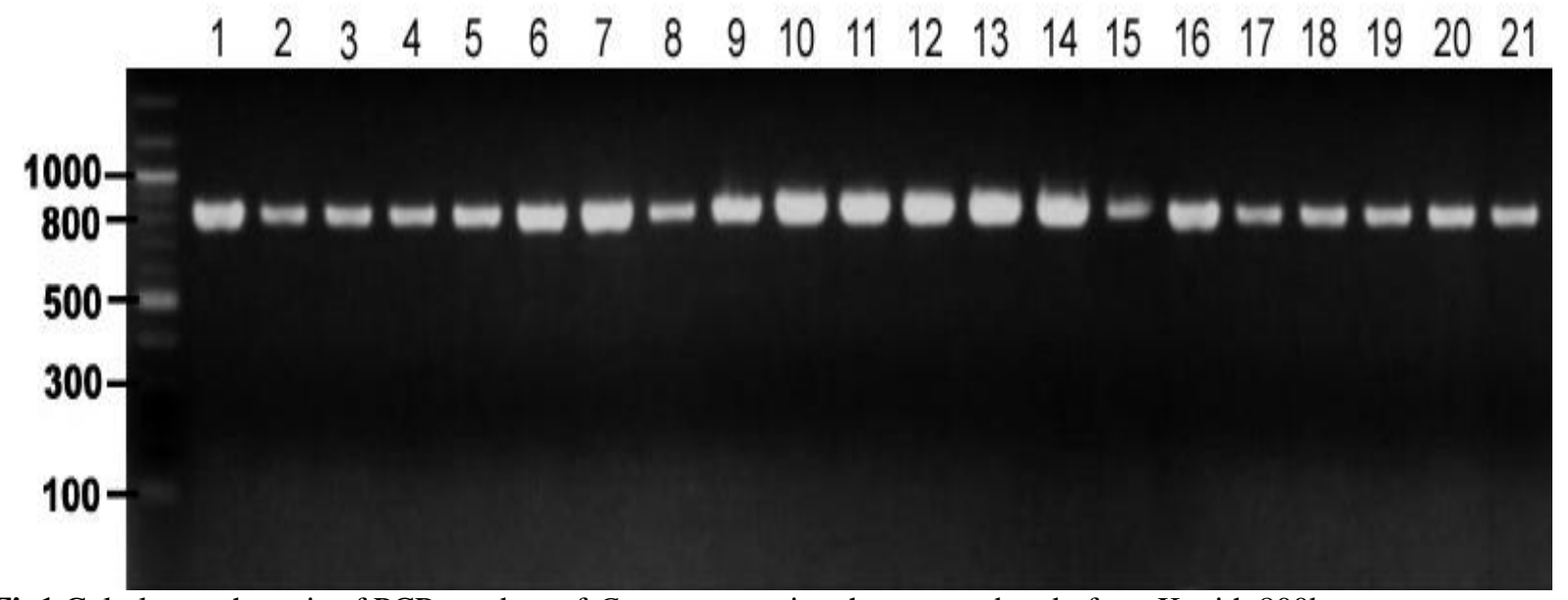

Fig1.Gel-electrophoresis of PCR product of Curcuma species shows a band of matK with 800bp.

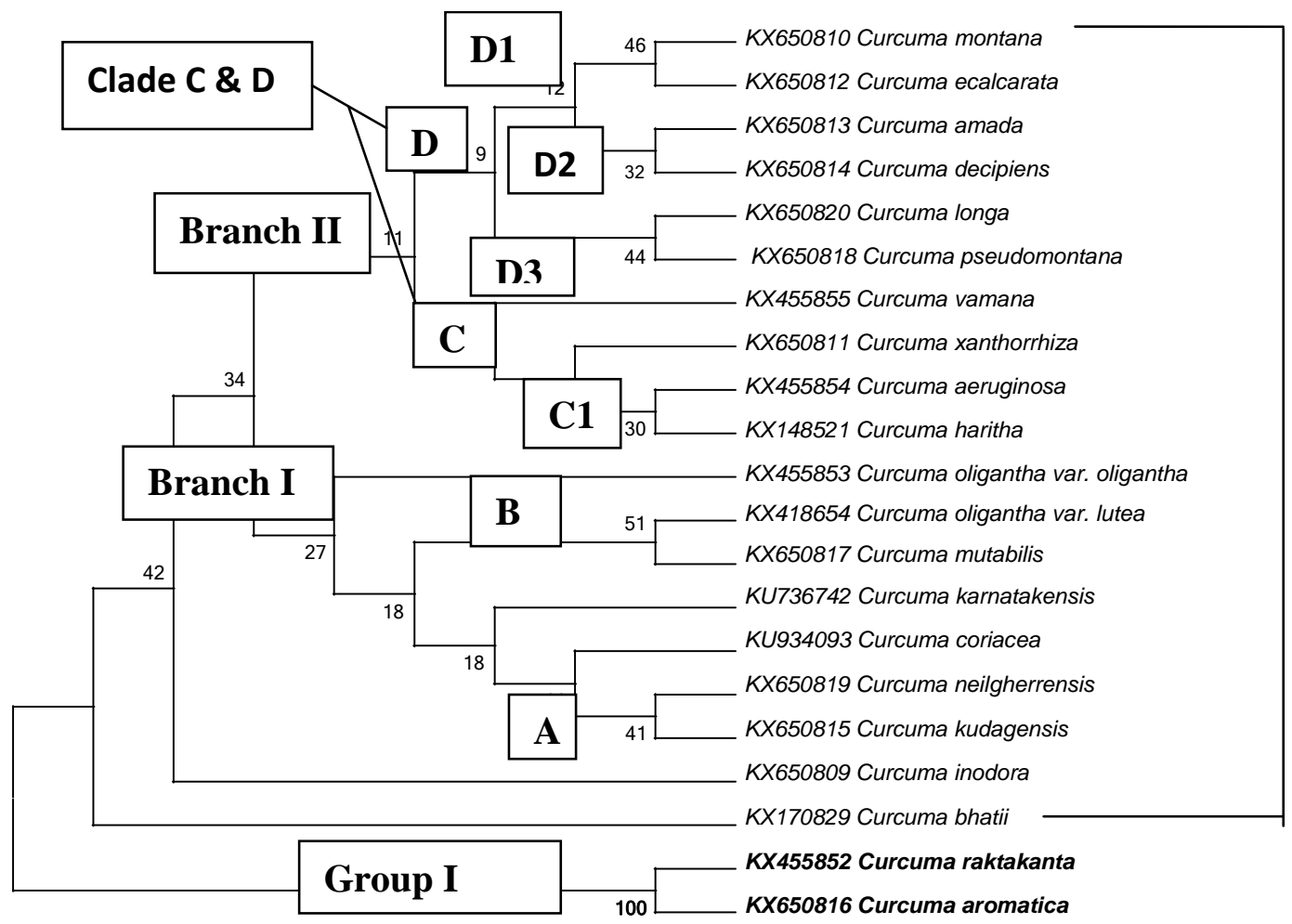

Group II

Fig 2:- Phylogenetic tree showing Evolutionary relationship between 21 Curcuma species inferred using the Neighbour joining method

\section{Discussion:-}

Chloroplast mat $\mathrm{K}$ gene is considered as one of the most rapidly evolving gene (Vijayan and Tsou, 2010).PCR and sequencing problems have been reported for matK gene (Sass, et al., 2007; Fazekas,et al., 2008; Ford,et al., 2009; 
Hollingsworth et al., 2009). PCR and sequence amplification success rate are important criteria for developing a DNA barcode (Kress and Erickson, 2007; Ford,et al., 2009; Hollingsworth et al., 2009).However, in the present study the results showed PCR and sequencing success rate of matK as high as $99 \%$.Transversions are considered illegitimate mutations in constructing phylogenies (Lake, 1987; Quicke, 1993). In recently diverged sequences the observed Transition/ transversion ratios were high. Transitions are higher than transversions for highly diverged sequences and low for less diverged sequences due to rate of higher transversions than transitions (Holmquist, 1983).Here, the observed low transition to transversion ( $\mathrm{Ts} / \mathrm{Tv}$ ) ratio (1.27) indicates comparatively high proportion of transversions in the gene. The evolutionary rate of mat $\mathrm{K}$ gene makes phylogenetically resolving intergeneric and interspecific relationships of many angiosperms (Johnson and Soltis, 1995; Soltis \& Soltis, 1998). According to Savolainenet al.,(2000a)the relationships revealed using matK data are more robust than those derived from combining $r b c L$ and $a t p B$ sequences.

Earlier intrageneric classifications of Curcuma were based on morphological characters using the position of the inflorescence that are confusing for many species (Škorničková, 2007). Molecular phylogenetic studies showed that Curcuma is a paraphyletic genus (Kress,et al., 2002; Ngamriabsakul, et al., 2004; Záveskáet al.,2012).Based on the morphological classification of the species $C$. haritha showed close relationship with C.aromatica and share a few characters with C.raktakanta, however C.raktakanta closely resembles C.aeruginosa in morphological character (Sabu,2006).Based on the molecular character related phylogenetic analysis, C.aromatica and C.raktakanta are close to each other. The present study showed the paraphyletic origin of these two species is moderate with (100\%) bootstrap value; however C.raktakanta did not show any relationship with C.aeruginosa. On morphological character, close relationship was established between C.karnatakensis and C.oligantha (Amalrajet al., 1999) that is incongruent with our work where these two species are grouped with different clade based on matK sequence data. However based on matK sequence both were placed in different clades.

\section{Conclusion:-}

The genus Curcuma of the family Zingiberaceae is complicated to differentiate using traditional morphological parameters because the morphological differences developed due to wide species hybridization. Then a Molecular marker based identification and phylogenetic analysis is required for these medicinal and economically important species. The current study suggests the effectiveness of matK gene sequences data to resolve phylogenetic relationship in the genus Curcuma. This study reveals the sequence variation, mean evolutionary rates, patterns and transition/transversion rate in nucleotide sequence, nucleotide diversity of matK gene can be used for the interpretation of evolutionary relationship within inter species level of genus Curcuma. The matK sequence successfully discriminated the closely related Curcuma species. So these sequences can be used as a DNA barcode for the genus Curcuma.

\section{Acknowledgements:-}

We are thankful to UGC (UGC grant F.NO. 43.107/2014) for financial assistance.

\section{Reference:-}

1. Amalraj, V.A., Velayudhan,K.C.,Muralidharan,V.K., 1999. Curcuma karnatakensis sp.Nov. (Zingiberaceae)Anew species from Uttar kannada District of Karnataka State. Journal of Economic and Taxonomic Botany 15(2):490-492.

2. Aoki, S., Ito,M., 2000. Molecular phylogeny of Nicotiana (Solanaceae) based on the nucleotide sequences of the matK gene. Plant Biology 2: 253-378.

3. Bakhuizen van den Brink Jr, R.C,. Zingiberaceae [M] // Baker C.A., 1968. Bakhuizen van den Brink Jr. RC. Flora of Java: Vol 3. Groningen: Wolters-Noordhoff N.V.,: 69-72.

4. Burtt, L.B. 1972. Key species in the taxonomic history of Zingiberaceae. Notes from the Royal Botanic Garden Edinburgh31: 224-227.

5. Cameron, K.M., Chase,M.W., Anderson,W.R., Hills,H.G.,2001. Molecular systematics of Malpighiaceae: evidence from plastid rbcL and matK sequences. American Journal of Botany 88: 1847-1862.

6. Chen, J., Xia, N.H., 2010. Chromosome cytology, leaf epidermal morphology and palynology of Curcuma rubrobracteata(Zingiberaceae). Nordic Journal of Botany, 28, 212-215.

7. Chen, Z.Y., Chen, S.J., Huang, S.F., 1984. Accounts of chromosomal number of Zingiberaceae (2) Guihaia 4: $13-18$. 
8. Doyle, J.J., Doyle J.L., 1987. A rapid DNA isolation procedure from small quantities of fresh leaf tissue.Phytochemical Bulletin. 19: 1-15.

9. Fazekas, A.J., Burgess, K.S., Kesanakurti, P.Ret al., 2008. Multiple multilocus DNA barcodesfrom the plastid genome discriminate plant species equally well. PLoS ONE, 3, 2802.

10. Ford, C.S., Ayres, K.L., Toomey, N.et al.,2009.Selection of candidate coding DNA barcodingregions for use on land plants.Botanical Journal of the Linnean Society, 159, 1-11.

11. Futuyma, J. D., 2005. Evolution.Sinauer Associates Inc., Sunderland, MA.

12. Goldman, D.H., Freudenstein,J.V., Kores,P.J.,Molvray,M., Jarrell,D.C., Whitten,W.M., Cameron,K.M., Jansen, R.K., Chase,M.W.,2001.Phylogenetics of Arethuseae (Orchidaceae) based on plastid matK and rbcL sequences. Systematic Botany 26: 670-695.

13. Hebert, P.D.N., Cywinska, A., Ball,S.L., DeWaard, J.R., 2003a.Biological identifications through DNA barcodes.Proceedings of the Royal Society B Biological Sciences 270: 313-321.

14. Hollingsworth, M.L., Clark, A., Forrest, L.L et al., 2009. Selecting barcod-ing loci for plants:evaluation of seven candidate loci with species level sampling in three divergent groupsof land plants. Molecular Ecology Resources, 9, 439-457.

15. Holmquist, R., 1983. Transitions and transversion in evolutionary descent: an approach to understanding. Journal of Molecular Evolution 19:134-144.

16. Hilu, K.W., Borsch,T., Muller,K., Soltis,D.E., Soltis,P.S., Savolainen,V., Chase,M.W., Powell,M., Alice,L.A., Evans,R.C., Sauquet,H., Neinhuis,C.,Slotta,T.A., Rohwer,J.G., Campbell,C.S.,Chatrou,L.,2003. Angiosperm phylogeny based on matK sequence information. American Journal of Botany 90: 1758-1776.

17. Johnson, L.S., Soltis, D.E., 1995. Phylogenetic inference in Saxifragaceaesensustricto and Gilia (Polemoniaceae) using matK sequences. Annals of the Missouri Botanical Garden 82:149-175.

18. Kress, W.J., Prince, L.M.,Williams, K.J.,2002. The phylogeny and a new classification of the gingers (Zingiberaceae): Evidence from molecular data. American Journal of Botany.89: 1682-1696.

19. Kress, W.J., Erickson, D.L., 2007. A two-locus global DNA barcode for land plants, the codingrbcLgene complements the non-coding trnH-psbAspacer region. PLoS ONE, 2, 508.

20. Lake, J.A., 1987. A rate-independent technique for analysis of nucleic acid sequences: evolutionary parsimony. Molecular Biology and Evolution 4:167-191.

21. Larsen, K., Lock, J.M., Maas, H.et al., 1998.Zingiberaceae. In: The Families and Genera of Vascular Plants (ed. Kubitzki K), pp. 474-495. Vol. 4. Springer-Verlag, Berlin.

22. Leong- Skornickova, J., Sida, O., Jarolımova, V.et al., 2007. Chromosome numbers and genome size variation in Indian species of Curcuma (Zingiberaceae). Annals of Botany, 100, 505-526.

23. Liang, H.P., Hilu, K.W., 1996. Application of the matK gene sequences to grass systematics. Canadian Journal of Botany 74: 125-134.

24. Ngamriabsakul, C., Newman, M.,Cronk, Q.B.C.,2004. The phylogeny of tribe Zingibereae (Zingiberaceae) based on ITS (nr DNA) and trnL-F (cp DNA) sequences. Edinburgh Journal o. Botany.60: 483-507.

25. Notredame, C., 2000. Journal of Molecular Biology, 205: 217.

26. Pazos, F., Valencia, A., 2001.Similarity of phylogenetic trees as indicator of protein-protein interaction. Protein Engineering. 14:609-614.

27. Quicke, D.L.J., 1993.Principle and techniques of contemporary taxonomy.Chapman \& Hall, Glasgow.

28. Rajesh Kumar T., Santhoshkumar R. Yusuf A (2016) Morphological characters and random amplified polymorphic DNA based genetic diversity analysis of curcuma species (zingiberaceae) from india. International Journal of Plant Animal and Environmental Sciences 6:37-52

29. Sabu, M., 2006.Zingiberaceae and Costaceae of South India.Association for Angiosperm Taxonomy. Page: 126186.

30. Sass, C., Little, D.P., Stevenson, D.W.et al., 2007.DNA barcoding in the cycadales, testing thepotential of proposed barcoding markers for species identification of Cycads.PLoS ONE,2, e1154.

31. Salazar, G.A., Chase,M.W., Arenas,M.A.S., Ingrouille,M.,2003.Phylogenetics of Cranichideae with emphasis on Spiranthinae (Orchidaceae, Orchidoideae): evidence from plastid and nuclear DNA sequences. American Journal of Botany 90: 777-795.

32. Savolainen, V., Chase, M.W., Hoot,S.B., Morton, C.M., Soltis,D.E., Bayer,C., Fay,M.F., De Bruijn,A.Y., Sullivan,S.,Qiu, Y.L.,2000a. Phylogenetics of flowering plants based upon a combined analysis of plastid $a t p B$ and $r b c L$ gene sequences. Systematic Biology 49: 306-362.

33. Škorničková, J.,2007.Taxonomic studies in Indian Curcuma L. Dissertation,Charles University, Prague, Czech Republic. 
34. Soltis, D.E., Soltis, P.S., 1998.Choosing an approach and an appropriate gene for phylogenetic analysis. In: Soltis DE, Soltis PS, Doyle JJ (eds) Molecular systematics of plants II: DNA sequencing. Kluwer, Dordrecht, pp 21-24.

35. Tajima, F., 1989.Statistical methods to test for nucleotide mutation hypothesis by DNA polymorphism.Genetics123:585-595.

36. Vijayan, K., Tsou, C.H., 2010. DNA barcoding in plants: taxonomy in a new perspective. CurrentScience 99(11):1530-1541.

37. Webb, C.O., Ackerly, D.D.,McPeek, M.A., Donoghue, M.J., 2002. Phylogenies and community ecology.Annual Review Ecology and Systematics33, 475-505.

38. Wolfe, K., 1987. Proceedings of the National Academy of Science, 9054: 9058.

39. Wolfe, K.H., 1991. Protein-coding genes in chloroplast DNA: compilation of nucleotide sequences, data base entries and rates of molecular evolution. In K. Vasil [ed.], Cell culture and somatic cell genetics of plants, 7 BI, 467-482. Academic Press, San Diego, California, USA.

40. Wolfe, K.H., Morden,C.W., Palmer,J.D., 1992. Function and evolution of a minimal plastid genome from nonphotosynthetic parasitic plants. Proceedings of the National Academy of Sciences, USA 89: 10648-10652.

41. Wu, D.L., Larsen, K., 2000. Zingiberaceae In: Flora of China, vol. 24 (eds Wu ZY \& Raven P), pp. 322-377. Science Press, Beijing and Missouri Botanical Garden Press, St. Louis, MO

42. Xiang, Q.Y.,Soltis,D.E., Soltis,P.S.,1998. Phylogenetic relationships of Cornaceae and close relatives inferred from matK and rbcL sequences. American Journal of Botany 85: 285-297.

43. Xiao, X.H., Liu, F.Q., Shi, C.H.et al., 2000.RAPD polymorphism and authentication of medicinal plants from Turmeric (Curcuma L.) in China [J].Chinese Traditional Herbal Drugs 31: 209-212.

44. Ye, X.B., Chen, J., Liu, N., 2008.Curcuma nankunshanensis (Zingiberaceae), a new species from China. Journal of Tropical and Subtropical Botany, 16, 472-476.

45. Zheng, M.L., Xia, Y.M., 2010.A investigation on the phylogeny of tribe Zingibereae (Zingiberaceae) based on nrDNA ITS and cpDNAmatK sequence data. Journal of Yunnan University 32(S1): 426-432.

46. Záveská, E., Fér, T., Šída, O.et al., 2012. Phylogeny of Curcuma (Zingiberaceae) based on plastid and nuclear sequences: Proposal of the new subgenus Ecomata. Taxon, 61,741-743. 